\title{
Seeding blue grama in old crested wheatgrass fields in southwestern Saskatchewan
}

\author{
JONATHAN D. BAKKER, JANICE CHRISTIAN, SCOTT D. WILSON, AND JOHN WADDINGTON
}

J. Bakker and J. Christian are graduate students and S. Wilson is associate professor, Department of Biology, University of Regina, Regina, Saskatchewan, S4S 0A2; J. Waddington is research scientist, Agriculture Canada, Semiarid Prairie Agricultural Research Centre, P.O. Box 1030, Swift Current, Saskatchewan, $S 9 H 3 X 2$.

\begin{abstract}
Crested wheatgrass [Agrapyron cristatum (L.) Gaertn,] fields have low plant diversity and a limited grazing season. We tested whether blue grama [Bouteloua gracilis (HBK.) Lag.] could be established in crested wheatgrass fields to increase plant diversity and grazing season length. Three seeding methods (unseeded, seed broadcast after rototilling, or seed drilled) and 2 herbicide treatments (none or glyphosate [ $N$ (phosphonomethyl)-glycine] sprayed at $1.1 \mathrm{~kg}$ a.i. $\mathrm{ha}^{-1}$ ) were applied in a complete factorial design to $3 \times 10$ m plots in 1994 in two 50 year-old crested wheatgrass stands. Blue grama established in seeded plots, but the effectiveness of seeding methods varied between sites. At both sites, herbicide control of crested wheatgrass greatly promoted the establishment of blue grama. Crested wheatgrass biomass and cover were reduced by rototilling and by spraying. The results suggest that the establishment of blue grama in crested wheatgrass stands is possible if seed is added and competition from crested wheatgrass is controlled.
\end{abstract}

Key Words: Bouteloua gracilis, Agropyron cristatum, competition, glyphosate, sod-seeding

Crested wheatgrass [Agropyron cristatum (L.) Gaettn.], an introduced grass from Asia, has been sown on more than 6 million ha of rangeland in the United States and Canada (Dewey and Asay 1975). Although crested wheatgrass stands provide valuable ground cover and forage, they offer limited potential for midsummer grazing as growth is completed by early summer (Rauzi 1975). In addition, crested wheatgrass stands still possess low plant diversity half a century after establishment (Hull and Klomp 1966; Looman and Heinrichs 1973; Marlette and Anderson 1986). Establishing native warm-season grasses into crested wheatgrass stands would increase grazing season length and plant diversity.

Crested wheatgrass was originally selected for use because of its relative ease of establishment (Hubbard 1949). Native grasses, in contrast, require adequate site preparation before seeding (Wark et al. 1995; Wilson and Gerry 1995) and seed of some

The authors thank M. Bast, M. Kalcounis, E. Bakker, and X. Li for field assistance, Grasslands National Park for housing and support, G. Ledingham for aid in species identification, and B. Larson for site histories. D. McCartney, E. Bakker, S. Hardegree and 2 anonymous reviewers provided helpful comments on earlier drafts of this manuscript. This study was funded by the Canada - Saskatchewan Agriculture Green Plan Agreement and Grasslands National Park.

Manuscript accepted 26 Apr. 1996. species is not widely available. Climatic conditions strongly influence establishment even with proper site preparation and seeding methods (Call and Roundy 1991). For example, blue grama [Bouteloua gracilis (HBK.) Lag.] establishment requires periods of sufficient moisture for germination and, several weeks later, adventitious root growth (Briske and Wilson 1980). Highly variable rainfall in the Great Plains (Sala et al. 1992) frequently results in establishment failure (Lauenroth et al. 1994).

Low plant diversity in crested wheatgrass stands may be due to the absence of seed of other species (Marlette and Anderson 1986), improper conditions for germination, or strong asymmetric competition between seedlings and established crested wheatgrass (Aguilera and Lauenroth 1995). We hypothesized that blue grama could be established in crested wheatgrass stands if seed was added and if crested wheatgrass growth was controlled by spraying.

\section{Materials and Methods}

The experiment was conducted in 1994 at 2 sites to account for spatial variation. The valley site was seeded to crested wheatgrass in 1948. It is located along the South Saskatchewan River in Saskatchewan Landing Provincial Park $\left(50^{\circ} 39^{\prime} \mathrm{N} 107^{\circ} 59^{\prime} \mathrm{W}\right), 50$ $\mathrm{km}$ north of Swift Current, Saskatchewan, Canada. The upland site, seeded to crested wheatgrass in 1946-47 (B. Larson, personal communication), is $175 \mathrm{~km}$ south of the valley site in Grasslands National Park, Saskatchewan $\left(49^{\circ} 22^{\prime} \mathrm{N} 107^{\circ} 53^{\prime} \mathrm{W}\right)$. Soils at both sites are brown chernozemic clay loams (Agriculture Canada 1992; Aridic Haploboroll, USDA-SCS 1975).

Both sites have semiarid climates, with mean annual temperatures and precipitation of around $4^{\circ} \mathrm{C}$ and $320 \mathrm{~mm}$ (Environment Canada 1993). From May to August 1994, the weather station nearest the valley site (Pennant, $20 \mathrm{~km}$ southwest) recorded average temperatures and precipitation levels. At Val Marie, $15 \mathrm{~km}$ northwest of the upland site, temperatures were hotter than average during the summer. May and June were wetter and July and August drier than average.

The experiment was conducted $>100 \mathrm{~m}$ into each crested wheatgrass field. Three seeding methods (unseeded, seed broadcast after rototilling, or seed drilled) and 2 spray treatments (none or glyphosate [ $N$ (phosphonomethyl)-glycine] sprayed at $1.1 \mathrm{~kg}$ a.i. $\mathrm{ha}^{-1}$ ) were applied in a complete factorial design to $3 \times 10 \mathrm{~m}$ plots separated by $1 \mathrm{~m}$ walkways. Treatment combinations were replicated 5 times. Plots were seeded with 23.4 and $19.5 \mathrm{~kg}$ pure live seed (PLS) ha ${ }^{-1}$ of blue grama at the upland and valley sites 
respectively. Plots were also seeded with needle-and-thread (Stipa comata Trin. \& Rupr.; 5.3 and $4.4 \mathrm{~kg}$ PLS ha $^{-1}$, respectively) and junegrass (Koeleria gracilis Pers.; 0.0 and $4.4 \mathrm{~kg} \mathrm{PLS} \mathrm{ha}^{-1}$, respectively), although neither of these grasses established. On 14 and 26 May, at the upland and valley sites respectively, the top $5 \mathrm{~cm}$ of soil in broadcast plots was rototilled and seed was hand broadcast. On 16 and 23 May, seed was drilled $1 \mathrm{~cm}$ deep in rows spaced $30 \mathrm{~cm}$ apart using a plot seeder with double-disk openers. Drilled plots were not rototilled. Spraying was meant to kill crested wheatgrass while affecting as few other species as possible; it was therefore applied on 11 and 18 May, before warm-season species began to grow. Glyphosate was applied in 220 liters ha $^{-1}$ of water at $150 \mathrm{kPa}$.

Seedlings were identified and counted on 30 June and 1 July and again on 16 and 22 August. Seedlings were counted in transects across the width of each plot. Plots with many seedlings had three $5 \mathrm{~cm}$ wide transects while plots with few seedlings had five $20 \mathrm{~cm}$ wide transects. Mean seedling density was determined for each plot.

The effects of the seeding and spray treatments were quantified in late August by measuring standing crop and cover of bare ground, litter (dead plant matter on soil surface), and each species present. At 3 points along the diagonal of each plot, $0.1 \times 1 \mathrm{~m}$ quadrats for standing crop and $0.5 \times 1 \mathrm{~m}$ quadrats for cover were established. All vegetation in the 3 standing crop quadrats of a plot was clipped at ground level, pooled, dried at $70^{\circ} \mathrm{C}$, and weighed. The current season's growth was not separated from previous growth. Cover was estimated using Daubenmire's scale (Mueller-Dombois and Ellenberg 1974). Cover estimates were averaged within each plot.

Data were tested for normality and heteroscedasticity and logtransformed as necessary. For each site, a 3 factor analysis of variance (ANOVA) tested the effects of seeding method (tilledand-broadcast or drilled), spray treatment (sprayed or unsprayed), and time (Junc or August) on seedling densitics. Unseeded plots contained no seedlings and were excluded from the ANOVA. A 2 factor ANOVA tested the effects of seeding method (unseeded, tilled-and-broadcast, drilled) and spray treatment (sprayed or unsprayed) on standing crop and cover of bare ground, litter, and the 3 most abundant species in each site in August.

\section{Results}

Blue grama established at both sites, with densities ranging from 5 to 760 seedlings $\mathrm{m}^{-2}$ in June and from 0 to 220 seedlings $\mathrm{m}^{-2}$ in August. No seedlings were found in unseeded plots.

\section{Valley Site}

Blue grama seedling densities tended $(P=0.06)$ to be higher in drilled than tilled-and-broadcast plots (Fig. 1; Table 1). Densities were significantly $(P<0.05)$ higher in sprayed than unsprayed plots, and significantly lower in August than June. A significant seed $X$ spray interaction resulted because seedling densities were higher in sprayed plots that were drilled rather than tilled-andbroadcast. Survivorship from June to August was higher in tilledand-broadcast than drilled plots, producing a significant seed $X$ time interaction. Survivorship was also higher in sprayed than unsprayed plots, producing a highly significant spray $X$ time interaction. The 3 -way interaction was not significant.
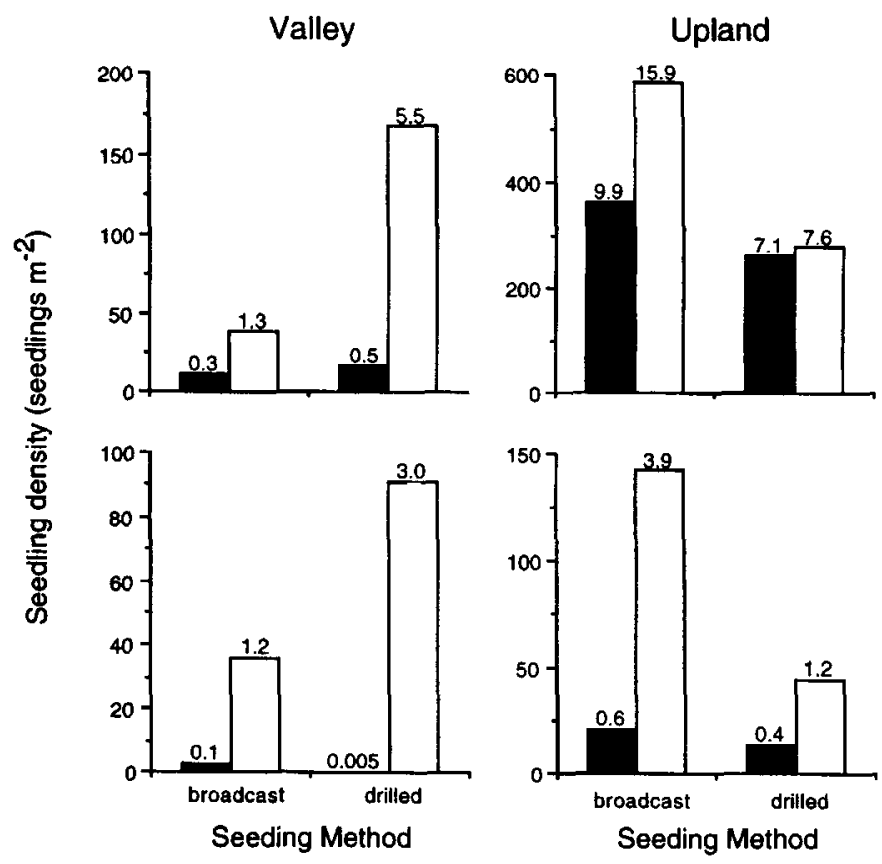

Fig. 1. June (top) and August (bottom) blue grama seedling densities at the valley and upland sites in 2 seeding methods in unsprayed (shaded) and sprayed (open) plots. The number above each bar is the seedling density as a proportion $(\%)$ of the number of sown seeds. No seedlings were found in unseeded plots. Broadeast plots were tilled prior to seeding. Note differences in scales. ANOVA results presented in Table 1.

Standing crop was significantly lower (Fig. 2) and cover of bare ground and litter significantly higher (Fig. 3) in tilled-andbroadcast than drilled or unseeded plots. Standing crop and bare ground cover were significantly lower in sprayed than unsprayed plots while litter cover was significantly higher.

Fifteen vascular plant species were identified, but crested wheatgrass composed 54\% of the cover in control plots. Only 3 other species, including some previously established blue grama, had $>1 \%$ cover in any treatment combination. Crested wheatgrass cover was significantly lower in tilled-and-broadcast than drilled or unseeded plots and in sprayed than unsprayed plots (Fig. 3). A significant seed $\times$ spray interaction resulted because crested wheatgrass cover was much lower in unsprayed plots that were tilled-and-broadcast rather than drilled or unseeded. Blue

Table 1. Results of 3 factor ANOVAs on blue grama seedling density in the valley and upland sites. Unseeded plots contained no seedlings and were excluded from the analysis. See Fig. 1 for means.

\begin{tabular}{lcc}
\hline \hline Source & \multicolumn{2}{c}{$F$} \\
\cline { 2 - 3 } & Valley Site & Upland Site \\
\hline Seeding Method $(\mathrm{S})$ & 3.76 & $18.57^{* * *}$ \\
Glyphosate Treatment $(\mathrm{G})$ & $136.92^{* * *}$ & $10.93^{* *}$ \\
Time $(\mathrm{T})$ & $26.05^{* * *}$ & $114.05^{* * *}$ \\
$\mathrm{~S} \times \mathrm{G}$ & $12.07^{* *}$ & $6.01^{*}$ \\
$\mathrm{~S} \times \mathrm{T}$ & $6.22^{*}$ & $6.45^{*}$ \\
$\mathrm{G} \times \mathrm{T}$ & $13.90^{* * *}$ & 0.55 \\
$\mathrm{~S} \times \mathrm{G} \times \mathrm{T}$ & 0.14 & 0.86 \\
\hline
\end{tabular}

*: $P<0.05 ; * *: P<0.01 ; * * *: P<0.001$ 

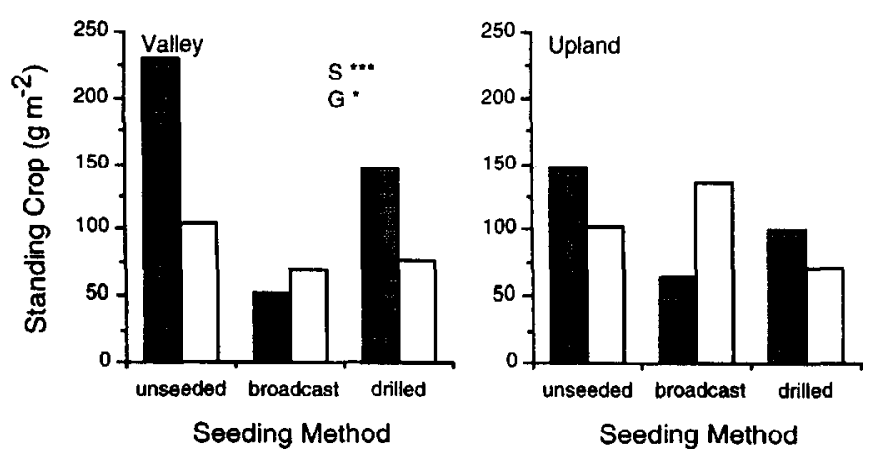

Fig. 2. August standing crop in the valley and upland sites in 3 seeding methods in unsprayed (shaded) and sprayed (open) plots. Broadcast plots were tilled prior to seeding. S: seeding method effect. G: spray treatment (glyphosate) effect. ${ }^{*}: P<0.05 ; * * *$ : $P<0.001$.

grama cover tended to be higher $(P=0.06)$ and low sedge (Carex stenophylla Wahl.) cover tended to be lower $(P=0.09)$ in sprayed than unsprayed plots.

\section{Upland Site}

Blue grama seedling densities were significantly higher in tilled-and-broadcast than drilled plots (Fig. 1; Table 1). Densities were significantly higher in sprayed than unsprayed plots and significantly lower in August than June. A significant seed $X$ spray interaction resulted because seedling densities were higher in sprayed plots that were tilled-and-broadcast rather than drilled. The seed $X$ time interaction was significant due to higher survivorship in tilled-and-broadcast than drilled plots. The spray $X$ time interaction and 3-way interaction were not significant.

Standing crop (Fig. 2) and litter cover (Fig. 3) did not vary with seeding method, but cover of bare ground was significantly higher in tilled-and-broadcast than drilled or unseeded plots. Neither standing crop, bare ground cover, or litter cover varied with spray treatment.

Sixteen vascular plant species were identified but, as at the valley site, crested wheatgrass composed most (45\%) of the cover of control plots. Four additional species had $>1 \%$ cover in any treatment combination. Crested wheatgrass cover was significantly lower in tilled-and-broadcast than drilled or unseeded plots (Fig. 3) but did not vary with spray treatment. Cover of the next most common species, spike moss (Selaginella densa Rydb.) and lichens, were not significantly affected by either treatment.

\section{Discussion}

Our results demonstrate that blue grama can be established in crested wheatgrass fields in southwestern Saskatchewan. Previous studies (Bement et al. 1965; Hyder et al. 1971) have shown a low establishment ability for blue grama in comparison to crested wheatgrass; this may be compensated for by using a high seeding rate.

Prairie restoration manuals recommend seeding with 7 to $11 \mathrm{~kg}$ PLS ha ${ }^{-1}$ if drilling and twice as much if broadcasting (Morgan et al. 1995; Wark et al. 1995). Successful seedings should have $>40$ plants $\mathrm{m}^{-2}$ by the end of the first season (Wark et al. 1995). Even though we used very high seeding rates, August densities were within this range only if crested wheatgrass was sprayed (Fig. 1).
Seeding at a very high rate and controlling the growth of crested wheatgrass were necessary to produce reasonable establishment.

The absence of ncedle-and-thread and junegrass seedlings may be due to seed dormancy. Needle-and-thread germinates $>1$ year after sowing (J. Bakker and J. Christian, unpublished data).

The absence of blue grama seedlings in unseeded plots, even when previously established blue grama was present (Fig. 3), supports other studies concluding that blue grama experiences little natural recruitment from seed (Hyder et al. 1971; Lauenroth et al. 1994). Precipitation patterns were suitable for establishment, as seedlings established in seeded plots.

Differences in seeding rate do not account for differences in seedling densitics between sites. The valley site was sown with four-fifths as much seed as the upland site, but had only one-fifth as many seedlings in June (Fig. 1). By August, seedling densities had declined to just over $1 \%$ of sown seeds at both sites. The lower survivorship rate at the upland site may be due to very low rainfall in July and August (16.2 and $71.4 \mathrm{~mm}$ at the upland and valley sites respectively).
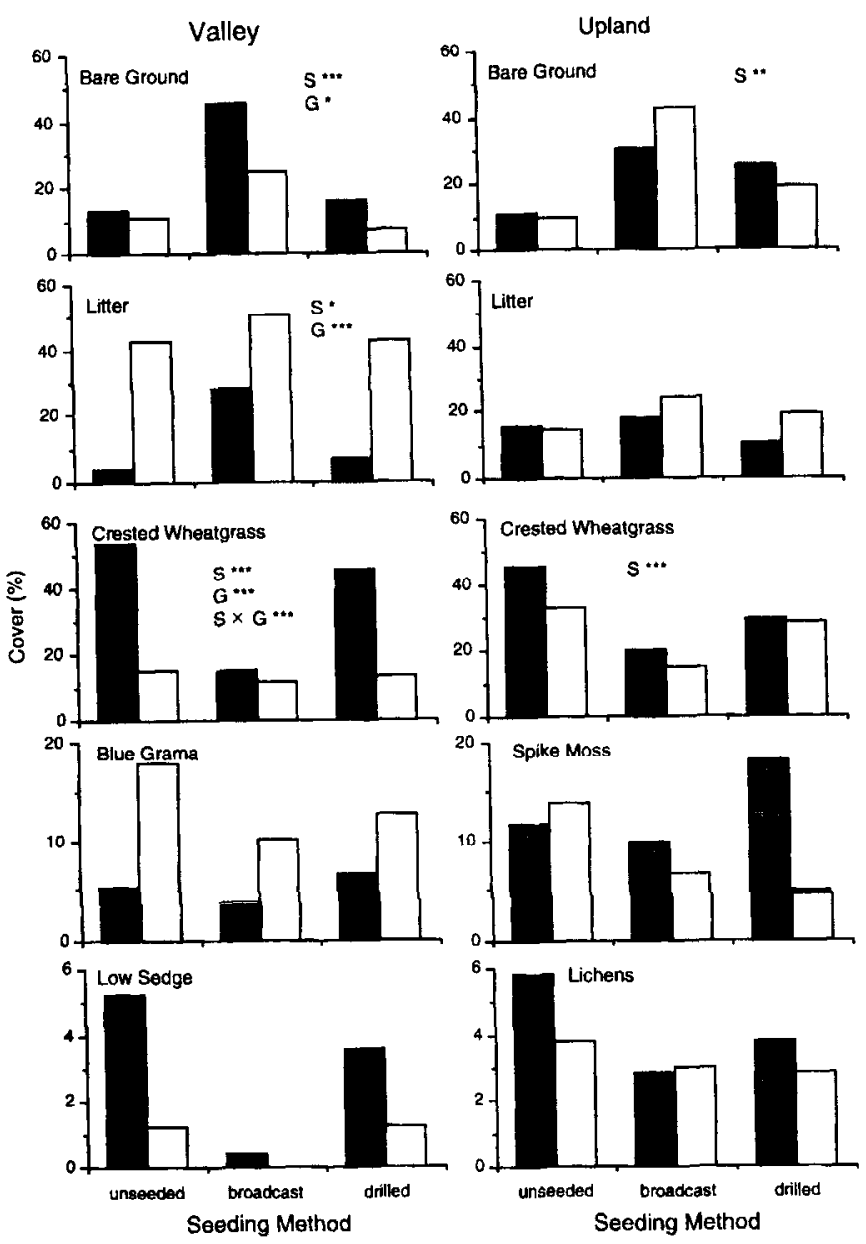

Fig. 3. Cover of bare ground, litter, and the 3 most common species in the valley and upland sites in 3 seeding methods in unsprayed (shaded) and sprayed (open) plots. Broadcast plots were tilled prior to seeding. Note differences in scales. S: seeding method effect. G: spray treatment (glyphosate) effect. ${ }^{*}: P<0.05 ;{ }^{*}: P<$ $0.01 ;{ }^{\star \star \star}: P<0.001$. 
The effectiveness of seeding methods varied between sites (Fig. 1), but survivorship at both sites was greater in tilled-and-broadcast than drilled plots. Variation in survivorship may be due to variation in competition for water. Higher crested wheatgrass cover in drilled plots suggests that interspecific competition may have been more intense in these plots. Competition between seedlings may have been greater in drilled plots as well, since drilled seed was restricted to rows while broadcast seed was dispersed over the entire plot.

Spraying reduced crested wheatgrass growth but had a minimal impact on other species (Fig. 3). Low sedge, the only other species reduced by spraying, is a cool-season species that was actively growing at the time of spraying. A single application of glyphosate suppressed the growth of crested wheatgrass but did not kill it. Gobin (1994) found that glyphosate application reduced the growth of existing vegetation for about 8 weeks, creating a period of reduced competition in which establishment could occur. The effect of spraying and rototilling on crested wheatgrass biomass in August varied between sites, possibly due to variation in the period of time between spraying and rototilling (Grossbard and Atkinson 1984) and later regrowth of crested wheatgrass.

In summary, our study showed that blue grama establishment was possible in crested wheatgrass stands if seed was added and crested wheatgrass growth was controlled. Seeding methods varied in effectiveness between sites, but control of crested wheatgrass growth was necessary at both sites. Future work should examine overwinter survival of blue grama seedlings, methods for establishing other species in crested wheatgrass stands, and establishment under other environmental conditions such as low soil nitrogen (Wilson and Gerry 1995). Precipitation varies spatially and temporally (Sala et al. 1992), so studies should also be replicated spatially or temporally.

\section{Literature Cited}

Agriculture Canada. 1992. Soil landscapes of Canada: Saskatchewan. Minister of Supply and Services Canada, Ottawa, Ontario.

Aguilera, M.O. and W.K. Lauenroth. 1995. Influence of gap disturbances and type of microsites on seedling establishment in Bouteloua gracilis. J. Ecol. 83:87-97.

Bement, R.E., R.D. Barmington, A.C. Everson, L.O. Hylton Jr., and E.E. Remmenga. 1965. Seeding of abandoned croplands in the central Great Plains. J. Range Manage. 18:53-59.

Briske, D.D. and A.M. Wilson. 1980. Drought effects on adventitious root development in blue grama seedlings. J. Range Manage. 33:323-327.

Call, C.A. and B.A. Roundy. 1991. Perspectives and processes in revegetation of arid and semiarid rangelands. J. Range Manage. 44:543-549.

Dewey, D.R. and K.H. Asay. 1975. The crested wheatgrass of Iran. Crop Sci. 15:844-849.

Environment Canada, Atmospheric Environment Service. 1993. Canadian climate normals, 1961-1990. Minister of Supply and Services Canada, Ottawa, Ontario.

Gobin, S.M. 1994. Evaluation of grass establishment, development, and survival under sod seeding conditions in the dry subhumid prairies. M.Sc. Thesis, Univ. Manitoba, Winnipeg, Manitoba.

Grossbard, E. and D. Atkinson. 1984. The herbicide glyphosate. Butterworths, London, U.K.

Hubbard, W.A. 1949. Results of studies of crested wheatgrass. Sci. Agr. 29:385-395.

Hull, A.C., Jr. and G.J. Klomp. 1966. Longevity of crested wheatgrass in the sagebrush grass type in southern Idaho. J. Range Manage. 19:5-11.
Hyder, D.N., A.C. Everson, and R.E. Bement. 1971. Seedling morphology and seeding failures with blue grama. J. Range Manage. 24:287-292.

Lauenroth, W.K., O.E. Sala, D.P. Coffin, and T.B. Kirchner. 1994. The importance of soil water in the recruitment of Bouteloua gracilis in the shortgrass steppe. Ecol. Appl. 4:741-749.

Looman, P.E. and D.H. Heinrichs. 1973. Stability of crested wheatgrass pastures under long-term pasture use. Can. J. Plant Sci. 53:501-506.

Marlette, G.M. and J.E. Anderson. 1986. Seed banks and propagule dispersal in crested wheatgrass stands. J. Appl. Ecol. 23:161-175.

Morgan, J.P., D.R. Collicutt, and J.D. Thompson. 1995. Restoring Canada's native prairies: A practical manual. Prairie Habitats, Argyle, Manitoba.

Mueller-Dombois, D. and H. Ellenberg. 1974. Aims and methods of vegetation ecology. John Wiley, New York, N.Y.

Rauzi, F. 1975. Seasonal yield and chemical composition of crested wheatgrass in southern Wyoming. J. Range Manage. 28:219-221.

Sala, O.E., W.K. Lauenroth, and W.J. Parton. 1992. Long-term soil water dynamics in the shortgrass steppe. Ecol. 73:1175-1181.

USDA-SCS. 1975. Soil taxonomy: A basic system of soil classification for making and interpreting soil surveys. Agr. Handbk. 436. U.S. Gov. Print. Off., Washington, D.C.

Wark, D.B., W.R. Poole, R.G. Arnott, L.R. Moats, and L. Wetter. 1995. Revegetating with native grasses. Ducks Unlimited Canada, Stonewall, Manitoba.

Wilson, S.D. and A.K. Gerry. 1995. Strategies for mixed-grass prairie restoration: Herbicide, tilling and nitrogen manipulation. Restor. Ecol. 3:290-298. 